\title{
LINGKUNGAN KERJA DAN KOMPENTENSI PEREKAM MEDIS TERHADAP KUALITAS SISTEM REKAM MEDIS DI RS AL ISLAM BANDUNG
}

\author{
Abdul Royani \\ Rekam Medis dan Informasi Kesehatan \\ Politeknik Piksi Ganesha, Jl. Jend. Gatot Soebroto No. 301 Bandung \\ Email: a.royanipiksi@gmail.com
}

\begin{abstract}
ABSTRAK
Pengaruh lingkungan kerja dan kompetensi perekam medis terhadap kualitas berkas rekam medis rumah sakit. Penelitian ini bertujuan untuk mengetahui hubungan pengaruh lingkungan kerja dan kompetensi perekam medis terhadap berkas rekam medis. Jenis penelitian deskriptif korelasi dengan pendekatan cross sectional. Teknik pengumpulan data menggunakan kuesioner dengan skala likert. Pengambilan sampel menggunakan total sampling atau sampling jenuh sebanyak 22 responden. Hasil penelitian menunjukkan bahwa; (1) Masih kurangnya pengetahuan perekam medis tentang 7 kompetensi perekam medis; (2) Masih kurangnya keterlibatan perekam medis dalam pembuatan berkas rekam medis; (3) Masih kurangnya hak akses perekam medis dalam pengolahan data berkas rekam medis; (4) Belum sesuai dalam penyajian data kualitas rekam medis dengan yang diharapkan dilapangan contoh report dari laporan yang akan disajikan; (5) Belum adanya Standar operasional prosedur pelepasan informasi dan hak akses kualitas rekam medis. Dari penelitian ini penulis menyarankan; (1) Meningkatkan pemahaman petugas tentang kompetensi yang harus dimiliki oleh setiap petugas rekam medis guna meningkatkan kualitas berkas rekam medis di RS Al-Islam Bandung; (2)Melakukan pendekatan dan lobi dengan unsur pimpinan rumah sakit mengenai penempatan tenaga rekam medis atau memberikan pelatihan tentang rekam medis kepada petugas yang ada secara berkala; (3) Merencanakan dan menyusun upaya peningkatan kesejahteraan perekam medis sesuai dengan kemampuan rumah sakit diantaranya seperti tunjangan fungsional bagi tenaga perekam medis; (4) Melakukan penelitian lebih lanjut tentang pengaruh kompetensi perekam medis terhadap kualitas berkas rekam medis; (5) Hasil penelitian ini dapat dijadikan sebagai bahan referensi atau data awal untuk mengembangkan penelitian terkait dengan kompetensi rekam medis dalam menunjang kualitas sistem informasi rekam medis.
\end{abstract}

Kata kunci: Lingkungan Kerja, Kompetensi, Kualitas, Berkas Rekam Medis

\begin{abstract}
The effect of work environment and competence of Medical Recordes on quality of Hospital medical record file.This study aims to determine the relationship between work environment and medical recorde's competence on the quality of medical record file of the hospital. The type of research in descriptive correlation with cross sectional approach. Data collection techniques used total sampling saturated
\end{abstract}




\begin{abstract}
sampling were 22 respondents. The result show that (1) There is still a lack of medical recorder knowledge about 7 medical record competetencies; (2) There is still a lack of medical recorder involvent on hospital record quality; (3) Still lack of acess to medical recorder in data processing quality of hospital medical record file (4) Not suitable in preseting quality data of hospital record file with expected in the field report of report to be presented; The absence of Standard procedure operational Disclosure of information and acess right to hospital medical record file quality. The result of this study the authors suggest (1) Improving the understanding of officers about the competencies that must be owned be the every medical record officer about the competencies that must be owned by every medical record files in hospitals Al-Islam Bandung; (2) Approach and lobby with elements of hospital management regarding the placement of medical record staff or provide training on the medical records to the existing officers regularly;(3)Planning and arranging effort to improve the walfare of medical recorders such as the ability of hospitals such as functional allowances for medical recorders;(4) conducting further research on the effect of working environment and medical recorder competence on the quality of hospital medical records file; (5) the result of this study can be used as reference material or preliminary data to develop research related to medical record competence in supporting the quality of medical record file in supporting the quality of medical record.
\end{abstract}

Keywords: Work Environment, Competence, Quality, Medical Record File

\title{
PENDAHULUAN
}

Rumah sakit sebagai suatu lembaga sosial yang memberikan pelayanan kesehatan kepada masyarakat, memiliki sifat sebagai suatu lembaga yang tidak ditujukan untuk mencari keuntungan. Pelayanan kesehatan rumah sakit mempunyai tiga pilar otoritas yang masing masing bekerja secara otonom namun harus terkoordinasi dalam sistem. Ketiga pilar tersebut adalah pilar pemilik, pilar professional, dan pilar manajemen. Walaupun demikian kita tidak dapat menutup mata bahwa dibutuhkan kualitas berkas rekam medis di dalam sistem rumah sakit.

Rumah sakit sebagai organisasi pelayanan di bidang kesehatan telah memiliki otonomi, sehingga pihak rumah sakit dituntut untuk memberikan pelayanan yang baik dengan manajemen yang seefektif mungkin. Hal ini disebabkan oleh setiap pengambilan keputusan yang tidak tepat akan berakibat pada in efisiensi dan penurunan kinerja rumah sakit.

Hal tersebut dapat menjadi kendala jika informasi yang tersedia tidak mampu memberikan informasi yang dibutuhkan dalam pengambilan keputusan. Kecanggihan teknologi bukan merupakan suatu jaminan akan terpenuhinya kualitas berkas rekam medis, melainkan sistem yang terstruktur, handal dan mampu mengakomodasi seluruh informasi yang dibutuhkan yang harus dapat menjawab tantangan yang dihadapi. Peran data dan kualitas berkas rekam medis dalam menyatukan upaya untuk mencapai visi bersama dari ketiga otoritas (pemilik, manajemen, dan staf profesional kesehatan) sehingga tercapai tujuan efficiency, equity, quality (EEQ).

Rumah sakit yang mempunyai salah satu unit terpenting yakni Unit Rekam Medis tidak terlepas pula dari kebutuhan akan sistem informasi. Di samping itu rekam medis yang merupakan refleksi sarana pendokumentasian data atau informasi utama di sarana pelayanan kesehatan menjadi sebuah kajian yang berarti bagi pihak yang menggunakannya. Berkas rekam medis yang mempunyai aspek legalitas dalam falsafahnya, dituntut harus lengkap, tepat dan akurat guna mengantisipasi tuntutan 
hukum oleh pihak tertentu kepada rumah sakit. Perkembangan teknologi informasi dan komunikasi yang melanda dunia kini pun telah berpengaruh besar bagi perubahan sudut pandang paradigma semua keilmuan, termasuk bidang kesehatan. Paradigma tentang rekam medis terkena dampaknya, sehingga dalam abad globalisasi sebutan profesi "rekam medis" (RM) menjadi profesi "manajemen informasi kesehatan" (MIK). Dampak perubahan ini bukan hanya pada pergantian RM menjadi MIK semata, tetapi seluruh wujud pengertiannya berubah dengan konsekuensi pada keseluruhan tata nilai keprofesian. Para praktisi manajemen informasi kesehatan sudah harus meningkatkan kualitas dirinya dalam memasuki abad 21.

Melihat sejarahnya, Menteri Kesehatan Republik Indonesia pernah membuat keputusan nomor 377/Menkes/SK/III/2007 tentang Standar Profesi Perekam Medis dan Informasi Kesehatan tanggal 27 Maret 2007 dan dilanjutkan dengan penyusunan Kriteria Unjuk Kerja (KUK) sebagai dasar kompetensi yang wajib dimiliki oleh seorang profesi Administrator Informasi Kesehatan ( Perekam Medis ) di Indonesia.

Administrator Informasi Kesehatan (Perekam Medis) sebagai profesi kesehatan dituntut untuk melaksanakan tugas dan fungsinya secara profesional, efektif dan efisien. Masyarakat secara penuh mempercayakan kebutuhannya untuk mendapatkan pelayaan informasi kesehatan yang bermutu dan bertanggung jawab.

Administrator Informasi Kesehatan ( Perekam Medis ) sebagai profesi mempunyai wewenang dan tanggung jawab untuk menetapkan hal hal yang berkaitan dengan lingkup keprofesiannya. Jika dikaitkan dengan sistem informasi, beberapa butir yang diimplementasikan dalam kompetensi perekam medis yakni mampu menghasilkan infromasi yang bermutu sebagai dasar perencanaan dan pengambilan keputusan di bidang pelayanan kesehatan. Dengan demikian sudah menjadi hal yang mutlak bahwa dalam menunjang kualitas informasi diperlukan adanya kompetensi, terutama dalam hal ini standar kompetensi dalam menunjang kualitas sistem informasi rumah sakit.

Menurut Pedoman Uji Kompetensi, Sertifikasi Dan Registrasi Tenaga Kesehatan Kementrian Kesehatan Republik Indonesia Majelis Tenaga Kesehatan Indonesia (MTKI) (2016 : 4), Kompetensi adalah kemampuan yang dimiliki seseorang tenaga kesehatan berdasarkan ilmu pengetahuan, keterampilan, dan sikap profesional untuk dapat menjalankan praktik dan atau pekerjaan keprofesian.

Unit Rekam Medis Rumah Sakit Al-Islam Bandung merupakan Unit yang menghasilkan kualitas berkas rekam medis. Data rekam medis merupakan alat komunikasi bagi seluruh system jaringan pelayanan kesehatan dirumah sakit, sehingga peran manajemen rekam medis dalam menunjang system informasi manajemen pelayanan kesehatan menjadi semakin penting. Unit rekam medis selain memberikan pelayanan langsung kepada pasien, juga berperan penting di dalam menyediakan data atau informasi tentang kegiatan pelayanan di rumah sakit, data yang dihasilkan dari unit rekam medis tersebut dapat digunakan untuk mengolah data yang selanjutnya dapat digunakan untuk menyusun pelaporan rumah sakit hal ini pun tergambar didalam kompetensi 5 Statistik Kesehatan.

Dilihat dari ketenagaan, jumlah perekam medis di Rumah Sakit Al-Islam Bandung berjumlah 22 orang dengan tingkat pendidikan sebagai berikut : S1 Kedokteran berjumlah 1 orang, D III Rekam Medis berjumlah 7 orang, SLTA berjumlah 12 orang. Dari hasil wawancara dengan perekam medis diperoleh alasan kalau mereka mengerjakan tugas sesuai dengan uraian tugas yang mereka kerjakan hal ini disebabkan terbatasnya tenaga perekam medis di Rumah Sakit Al-Islam Bandung, sehingga kualitas berkas rekam medis belum dirancang secara maksimal hal ini memerlukan kompetensi perekam medis. Oleh karena itu perekam medis selalu melakukan analisis kualitas berkas rekam medis dengan berusaha berkoordinasi dengan Unit lain dan meningkatkan 
kompetensi perekam medis di Rumah Sakit Al-Islam Bandung terlebih dahulu perlu diketahui bagaimana pengetahuan kompetensi perekam medis dalam melaksanakan kualitas berkas rekam medis.

Pada saat kualitas berkas rekam medis secara terintegrasi dengan duduk bersama hal ini pun terkait dengan faktor pengaruh kompetensi perekam medis terhadap kualitas berkas rekam medis. Memperhatikan permasalahan yang ditemui pada Unit Rekam Medis Rumah Sakit Al-Islam Bandung sangatlah penting dalam meningkatkan kualitas berkas rekam medis melibatkan kompetensi perekam medis.

\section{METODOLOGI PENELITIAN}

Kualitas berkas rekam medis fokus dari sistem ini adalah menyediakan laporan dan informasi yang dibutuhkan oleh manajer untuk pengelolaan rutin. Jenis laporan yang umum disediakan oleh sistem ini meliputi laporan periodik terjadwal, laporan pengecualian, laporan permintaan dan lain-lain. Ketika para manajer menentukan output yang harus disediakan pengolah informasi, mereka mempertimbangkan empat dimensi dasar informasi yaitu dengan kualitas berkas rekam medis yang relevansi, akurasi, ketepatan waktu, kelengkapan. Hal ini harus didukung dengan kompetensi perekam medis dalam pengolahan data dengan cepat dan akurat.

Permasalahan yang diindentifikasi dalam penelitian ini adalah: (a) Masih kurangnya pengetahuan perekam medis tentang 7 kompetensi perekam medis yang meliputi kompetensi klasifikasi dan kode penyakit, aspek hukum dan etika profesi, manajemen rekam medis dan informasi kesehatan, menjaga mutu rekam medis, statistik kesehatan, manajemen unit kerja rekam medis dan informasi kesehatan, dan kemitraan profesi. (b) Masih kurangnya keterlibatan perekam medis dalam pembuatan kualitas berkas rekam medis. (c) Masih kurangnya hak akses perekam medis dalam pengolahan data kualitas berkas rekam medis. (d) Belum sesuai dalam penyajian data kualitas berkas rekam medis dengan yang diharapkan dilapangan contoh report dari laporan yang akan disajikan.

Tabel 1. Operasional Variabel

\begin{tabular}{|c|c|c|c|}
\hline Variabel $\left(\mathbf{X}_{1}\right)$ & Dimensi & Indikator & Skala \\
\hline Kompetensi & 1. Kompetensi & Kompetensi 1: & Ordinal \\
\hline Perekam Medis & $\begin{array}{l}\text { Klasifikasi dan } \\
\text { Kode Penyakit }\end{array}$ & $\begin{array}{l}\text { 1. Menentukan nomor kode diagnosis } \\
\text { pasien sesuai petunjuk dan }\end{array}$ & \\
\hline Kompetensi Perekam & 2. Kompetensi Aspek & peraturan pada buku pedoman ICD & \\
\hline Medis merupakan & Hukum dan Etika & yang berlaku (ICD-10 Volume 2) & \\
\hline kemampuan seorang & Profesi & 2. Mengumpulkan kode diagnosis & \\
\hline individu yang & 3. Kompetensi & pasien untuk memenuhi sistem & \\
\hline mencakup & Manajemen & pengelolaan, penyimpanan data & \\
\hline pengetahuan, & Rekam Medis dan & pelaporan untuk kebutuhan sistem & \\
\hline $\begin{array}{lr}\text { keterampilan } & \text { dan } \\
\text { sikap kerja } & \text { yang }\end{array}$ & $\begin{array}{l}\text { Informasi } \\
\text { Kesehatan }\end{array}$ & $\begin{array}{l}\text { analisis sebab tunggal penyakit } \\
\text { yang dikembangkan }\end{array}$ & \\
\hline sesuai standar yang & 4. Kompetensi & 3. Mengklasifikasikan & \\
\hline ditetapkan. & Menjaga Mutu & diagnosis yang akurat bagi & \\
\hline Menurut Pedoman & Rekam Medis & kepentingan informasi morbiditas & \\
\hline Uji Kompetensi, & 5. Kompetensi & dan sistem pelaporan morbiditas & \\
\hline Sertifikasi Dan & Statistik & yang diharuskan & \\
\hline Registrasi Tenaga & Kesehatan & Menyajikan informasi morbiditas & \\
\hline Kesehatan & 6. Kompetensi & dengan akurat dan tepat waktu bagi & \\
\hline Kementerian & Manajemen Unit & kepentingan monitoring KLB & \\
\hline Kesehatan Republik & Kerja $\quad$ Rekam & epidemiologi dan lainnya & \\
\hline
\end{tabular}




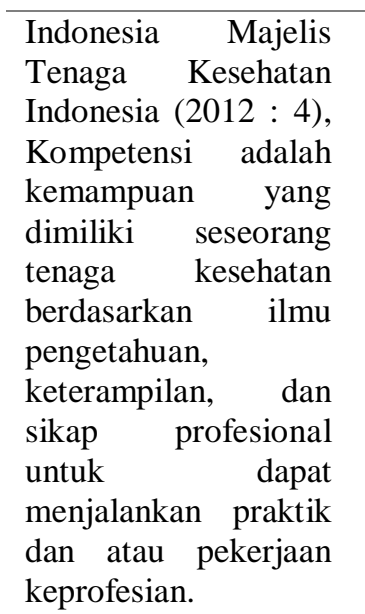

Medis dan
Informasi
Kesehatan
7. Kompetensi
Kemitraan Profesi

5. Mengelola indeks penyakit dan tindakan guna laporan kepentingan medis dan statistik serta permitaan informasi pasien secara cepat dan terperinci

6. Menjamin validitas data untuk registrasi penyakit

7. Mengembangkan dan menginplementasikan petunjuk standar koding dan pendokumentasian

Kompetensi 2:

1. Mempfasilitasi pelepasan informasi kesehatan kepada pasien maupun pihak ketiga.

2. Menyiapkan informasi pasien kepada pihak yang berhak.

3. Menjaga keamanan alur permintaan informasi kesehatan pasien.

4. Memelihara kerahasiaan informasi pasien.

5. Mengidentifikasi resiko tinggi dalam kerahasiaan informasi pasien.

6. Mengevaluasi faktor resiko dalam peendokumentasian dan kerahasiaan informasi kesehatan.

7. Melaksanakan kebijakan dan prosedur akses dalam pelepasan informasi.

8. Melaksanakan kebijakan dan prosedur terkait dengan peraturan dan dokumentasi.

9. Mengkoordinasikan kegiatan komite keamanan informasi kesehatan.

10. Membuat pedoman training, peraturan dan prosedur yang terkait dengan informasi pelayanan pasien.

Kompetensi 3:

1. Meregistrasi atas semua kunjungan yang ada difasilitas pelayanan kesehatan (registrasi pendaftaran rawat jalan dan rawat inap)

2. Memberikan nomor rekam medis secara berurutan dan sistematis berdasarkan sistem yang digunakan (penomoran seri, unit, seri unit)

3. Menulis nama pasien dengan baik dan benar sesuai dengan sistem yang digunakan

4. Membuat indeks pasien (kartu atau media lainnya)

5. Menyusun (assembling) rekam medis dengan baik dan benar berdasarkan SOP yang ada 
6. Menganalisis rekam medis secara kuantitatif dengan tepat meliputi

1) Kebenaran identifikasi

2) Adanya laporan-laporan yang penting

3) Autentikasi

7. Pendokumentasian yang baik

8. Menganalisis rekam medis secara kualitatif guna konsistensi isi dan mutu rekam medis

9. Menyimpan/menjajarkan rekam medis berdasarkan sistem yang digunakan (Stragiht Numeical, Middle Digit, dan Terminal Digit Filing System)

10. Mengambil kembali (retrieval) dengan cepat rekam medis yang diperlukan untuk memenuhi kebutuhan asuhan pasien dan berbagai kebutuhan lainnya

11. Melakukan penyusutan (retensi) rekam medis berdasarkan peraturan dan perundang-undangan yang berlaku

12. Mendisain formulir rekam medis

\section{Kompetensi 4}

1. Melaksanakan program kegiatan menjaga mutu (QA) rek medis

2. Melakukan pemeriksaan ulang (quality review) MIK/rekam medis.

3. Melakukan analisis untuk mengkaji kekuatan, kelemahan, peluang dan ancaman,

("SWOT") MIK/rekammedis

4. Menyelenggarakan kegiatan yang merupakan prioritas sasaran mutu pelayanan MIK/rekam medis

5. Melakukan penilaian dan memberikan solusi terhadap sistem komputerisasi pelayanan MIK/RM

6. Mempersiapkan laporan untuk badan akreditasi, lisensi dan sertifikasi dalam memenuhi standar akreditasi dan kebijakan yang terkait dengan perekam medis

7. Memonitor kesesuaian kebijakan dan prosedur agar tetap relevan dengan manajemen data klinis.

8. Meningkatkan kualitas data klinis dalam proses menjaga mutu MIK/rekam medis

\section{Kompetensi 5}

1. Mengidentifikasi informasi yang dibutuhkan sebagai dasar pengambilan keputusan

2. Mendisain formulir untuk tahap pengumpulan data kesehatan 
3. Mengumpulkan data untuk manajemen mutu, manajemen penggunaan, manajemen resiko dan penilaian lain yang berhubungan dengan asuhan pasien

4. Mengelola data penyusunan laporan efisiensi pelayanan pada pada sarana pelayanan kesehatan.

5. Melakukan analisis statistik sederhana

6. Mendemonstrasikan atau presentasi data laporan ke berbagai pihak

7. Menggunakan aplikasi komputer untuk pengumpulan, pengolahan dan penyajian informasi kesehatan

8. Memberi konstribusi penggunaan fungsi data klinis, administrasi dan eksternal

9. Mengumpulkan dan Menganalisa data untuk (kebutuhan khusu) proyek riset klinis

10. Menerapkan rencana manajemen kualitas data (menjaga konsistensi data)

11. Monitoring pelaksanaan kebijakan data prosedur manajemen sumber data organisasi

12. Mengelola kualitas data di sarana pelayanan kesehatan.

\section{Kompetensi 6}

1. Memprediksi kebutuhan informasi dan teknik dalam sistem pelayanan kesehatan dimasa yang akan datang

2. Melaksanakan rencana strategis, goal dan objektif untuk area tanggung jawabnya

3. Merencanakan kebutuhan sarana dan presarana unit kerja MIK/RM untuk memenuhi kebutuhan kerja

4. Menyusun anggaran/budget

5. Menggunakan anggaran/budget

6. Menerapkan program orientasi dan latihan staf bagi yang terkait dalam sistem pelayanan kesehatan

7. Menyusun kebijakan dan prosedur tentang MIK/RM yang sesuai dengan hukum, sertifikasi, akreditasi, dan kebutuhan setempat

8. Mengembangkan kebijakan dan prosedur tentang MIK/RM yang sesuai dengan hukum, sertifikasi, akreditasi, dan kebutuhan setempat

9. Mengimplementasikan kebijakan dan prosedur tentang MIK/RM yang sesuai dengan hukum, sertifikasi, akreditasi, dan kebutuhan setempat 
10. Mengevaluasi kebijakan dan prosedur tentang MIK/RM yang sesuai dengan hukum, sertifikasi, akreditasi, dan kebutuhan setempat

11. Menyusun analisa jabatan dan uraian tugas perekam medis/perekam medis

12. Menyusun kebijakan dan prosedur antara unit kerja tentang arus informasi setempat

13. Mengembangkan sistem MIK/RM sebagai bagian dari perencanaan sistem informasi dalam sistem pelayanan kesehatan.

14. Merencanakan masalah pengembangan, solusi, pembuatan keputusan dan rencana strategi unit kerja MIK/RM

15. Menyajikan informasi hasil kerja penyelenggaraan MIK/RM guna evaluasi kinerja unitnya

16. Memonitor keadaan staf, produktifitas dan arus kerja untuk tujuan pengawasan

17. Melaksanakan dokumentasi unit kerja MIK/RM

18. Meningkatkan pelayanan prima sarana pelayanan kesehatan sesuai harapan pasien

19. Menyiapkan profil rumah sakit

20. Mengoprasikan komputer guna penyelenggaraan sistem MIK/RM

\section{Kompetensi 7}

1. Melaksanakan komunikasi efektif dengan semua tingkatan

2. Mengikuti berbagai kegiatan sosialisasi antar profesi kesehatan, non kesehatan dan atar organisasi yang berkaitan dengan profesi

3. Memberikan informasi database MIK dengan efisien dan efektif

4. Mengidentifikasi kebutuhan informasi bagi pelanggan baik internal dan eksternal

5. Melaksanakan komunikasi dengan teknoligi mutakhir (internet, email, fax dll)

6. Melaksanakan negosisi dan advokasi tentang pelayanan MIK/RM

7. Memberikan konsultasi dalam pengelolaan informasi kesehatan sesuai dengan wewenang dan tanggung jawabnya

8. Menjalin kerjasama dengan bagian Sistem Informasi RS dalam pengembangan teknologi baru 
9. Memberikan konsultasi pendidikan dan latihan bagi pengguna layanan informasi.

\section{Karakteristik Lingkungan Kerja}

Menurut Nitisemito (2013:97),

Karakteristik lingkungan kerja adalah segala sesuatu yang ada disekitar karyawan dan dapat mempengaruhi dalam menjalankan tugas yang diembankan kepadanya misalnya dengan adanya air conditioner (AC), penerangan yang memadai dan sebagainya.
1. Usia

Nominal

2. Jenis Kelamin

3. Pendidikan

4. Status kepegawaian

5. Lama Kerja
Nominal

Ordinal

Nominal

Ordinal

\section{Kualitas Berkas \\ Rekam Medis}

Kualitas Berkas

Rekam Medis adalah

Totalitas fitur dan karakteristik produk atau jasa yang bergantung pada kemampuannya untuk memuaskan kebutuhan yang dinyatakan dan kumpulan informasi berkait yang diberi nama dan direkam pada tempat penyimpanan sekunder berkas yang berisikan catatan dan dokumen tentang identitas pasien, pemeriksaan,

pengobatan, tindakan dan pelayanan lain yang telah diberikan kepada pasien.
1. Relevan (relevancy)

2. Akurat (accuracy)

3. Tepat waktu (timeliness)

4. Ekonomis (economy)

5. Efisien(efficiency)

6. Dapat dipercaya (reliability)
1. Kemudahan akses, artinya sistem perolehan data tersedia setiap waktu selama 24 jam dan hanya dapat dibuka oleh pihak yang berwenang

2. Berkualitas, informasi yang berkualitas menjadi suatu persyaratan dalam menyimpan rekam medis/kesehatan dan RKE (rekam kesehatan elektronik)

3. Kurang atau hilangnya data dengan sendirinya memengaruhi pengambilan keputusan tentang diagnosis dan tindakan

4. Informasi akurat, artinya data menggunakan nilai yang benar dan valid

5. Informasi mudah diakses, artinya butiran data mudah diperoleh, layak dikumpulkan dan mempunyai nilai legal

6. Informasi bersifat menyeluruh (comprehensive), artinya data dikumpulkan secara luas, lengkap meski ada keterbatasannya

7. Informasi konsisten, artinya nilai data dan aplikasi harus sama-sama dapat dipercaya

8. Informasinya mutakhir (up to date), artinya nilai tukar data (kurensi) harus senantiasa yang
Nominal

Nominal

Ordinal

Nominal

Ordinal

Ordinal 
9. Definisi jelas, artinya definisi data harus dijelaskan dengan terang dan jernih sehingga mudah dimengerti dan tahu batasannya

10. Ada butiran data, artinya atribut nilai data harus dijabarkan pada tingkatan yang benar (misalnya sensus)

11. Informasi tepat, artinya nilai data harus cukup besar untuk mendukung aplikasi atau proses

12. Ada hubungannya (relevant), artinya data berguna bagi kinerja proses dan aplikasi

13. Masukan data (entry) dan catat sebagaimana seharusnya dengan benar (timeliness)

14. Informasi menjaga keamanan (security), privasi (privacy), kerahasiaan (confidentiality), dan keselamatan (safety) akan data dan informasinya

15. Informasi dapat dihubungkan dengan berbagai sumber (connectivity) dan efisien

\section{HASIL DAN PEMBAHASAN}

Dengan mengikuti dimensi operasional variable pada Tabel.1, penelitian ini dilakukan terhadap responden dengan jenis kelamin laki-laki sebanyak 32\% dan responden perempuan sebanyak $68 \%$. Pada umumnya masa kerja responden (45\%) adalah sudah lebih dari 5 tahun.

Regresi antara variabel lingkungan kerja, kompetensi perekam dan kualitas berkas perekam medis terhadap kinerja dapat digambarkan dalam pengolahan data dengan software SPSS versi 22.00 . Nilai $\mathrm{R}^{2}$ (koefisien determinasi) sebesar 0,295 . Hal ini menunjukkan bahwa besarnya variasi yang memberikan pengaruh bersama-sama antara Pengaruh lingkungan kerja, Kompetensi perekam medis, terhadap Kualitas Berkas Rekam Medis sebesar 36,4 \% atau sisanya 63,6\% dipengaruhi oleh faktor-faktor lain yang tidak diteliti.

Hasil pengujian hipotesis telah membuktikan terdapat pengaruh antara kompetensi Perekam Medis terhadap kualitas berkas. Melalui hasil perhitungan yang telah dilakukan diperoleh nilai $\mathrm{t}$ hitung sebesar -1,624. Nilai taraf signifikansi sebesar -1,624 tersebut lebih kecil dari 0,05, yang berarti bahwa hipotesis dalam penelitian ini menolak $\mathrm{H}_{\mathrm{a}}$ dan menerima $\mathrm{H}_{\mathrm{o}}$. Pengujian ini secara statistik membuktikan bahwa kompetensi perekam medis berpengaruh negatif terhadap kualitas berkas artinya bahwa variabel kompetensi perekam medis secara signifikan tidak mempengaruhi kualitas berkas rekam medis di Rumah Sakit Al-Islam Bandung. Adanya kompetensi perekam medis yang kurang baik maka kinerja karyawan RS Al-Islam Bandung akan kurang baik, dengan demikian semakin RS Al-Islam Bandungtidak dapat meningkatkan Kompetensi Perekam Medis maka kualitas berkas rekam medis pun akan semakin kurang baik. 


\section{SIMPULAN}

Berdasarkan hasil penelitian mengenai pengaruh lingkungan kerja dan kompetensi perekam medis terhadap kualitas berkas rekam medis rumah sakit, di Rumah Sakit Al Islam Bandung maka dapat ditarik kesimpulan sebagai berikut:

Diperoleh nilai koefisien regresi pada variabel lingkungan kerja adalah sebesar 0,167. Ini berarti bahwa jika faktor lain dianggap konstan, pengaruh lingkungan kerja lebih besar dibandingkan dengan kompetensi perekam medis. Pengujian ini secara statistik membuktikan bahwa Lingkungan kerja berpengaruh positif terhadap kinerja karyawan, artinya bahwa ada pengaruh antara variabel lingkungan kerja terhadap kualitas berkas rekam medis di RS Al Islam Bandung, hal ini disebabkan dengan adanya lingkungan kerja yang baik maka kinerja karyawan RS Al Islam pun akan menjadi baik pula.

Nilai koefisien regresi pada variabel kompetensi perekam medis adalah sebesar 0,121. Maka setiap peningkatan kompetensi perekam medis maka kinerja akan ikut meningkat sebesar 0,121. Pengujian ini secara statistik membuktikan bahwa kompetensi perekam medis berpengaruh negatif terhadap kualitas berkas artinya bahwa variabel kompetensi perekam medis secara signifikan tidak mempengaruhi kualitas berkas rekam medis di RumahSakit Al Islam Bandung, hal ini disebabkan dengan adanya kompetensi perekam medis yang kurang baik maka kinerja karyawan RS Al Islam Bandung akan kurang baik, dengan demikian semakin RS Al Islam Bandung tidak dapat meningkatkan kompetensi perekam medis maka kualitas berkas rekam medis pun akan semakin kurang baik.

Variabel yang paling dominan, yang mempunyaikoefisien beta $=1,195$ adalah pengaruh lingkungan kerja diikuti oleh variabel kompetensi perekam medis dengan koefisien beta $=-1,351$. Variabel lingkungan kerja, kompetensi perekam medis secara bersama sama tidak berpengaruh terhadap kualitas berkas rekam medis. Secara simultan semua variabel bebas berpengaruh signifikan terhadap variabel terikat dengan nilai sig. $0,259<\alpha 0,05$.

Berdasarkan hasil penelitian mengenai pengaruh lingkungan kerja dan kompetensi perekam medis terhadap kualitas berkas rekam medis rumah sakit, di Rumah Sakit Al-Islam Bandung, maka terdapat beberapa saran bagi Manajemen Rumah Sakit Al Islam Bandung: (a) Meningkatkan pemahaman petugas tentang kompetensi yang harus dimiliki oleh setiap petugas rekam medis guna meningkatkan kualitas berkas rekam medis di RS Al Islam Bandung, (b) Merencanakan dan menyusun upaya peningkatan kesejahteraan perekam medis sesuai dengan kemampuan rumah sakit diantaranya :tunjangan fungsional bagi tenaga perekam medis (c) Melakukan penelitian lebih lanjut tentang pengaruh lingkungan kerja dan kompetensi rekam medis terhadap kualitas berkas rekam medis, (d) Hasil penelitian ini dapat dijadikan sebagai bahan referensi atau data awal untuk mengembangkan penelitian terkait dengan pengaruh lingkungan kerja dan kompetensi rekam medis dalam menunjang kualitas berkas rekam medis.

Adapun saran bagi Praktisi Perekam Medis Rumah Sakit Al-Islam Bandung: (a) Melakukan pendekatan secara berkesinambungan melakukan pendekatan dan lobi dengan unsur pimpinan rumah sakit mengenai penempatan tenaga rekam medis atau memberikan pembinaan dan pelatihan tentang rekam medis kepada petugas yang ada secara berkala dengan unsur pimpinan rumah sakit mengenai penempatan tenaga rekam medis atau memberikan pembinaan dan pelatihan tentang rekam medis kepada petugas yang adasecara berkala, (b) Praktisi perekam medis yang ada harus 
bisa memberikan wawasan keilmuanya tentang sistim rekam medis kepada rekam yang secara formal belum mempunyai ilmu secara formal tentang rekam medis, (c) Memberikan contoh dan tauladan bagi rekan kerja yang belum maksimal dalam menjalankan tugasnya sebagai seorang praktisi perekam medis, dan (d) Memberikan kepuasan pelanggan internal maupun eksternal dalam menjalan kan tugasnya yang disesuaikan dengan standar prosedur operasional yang ada.

\section{DAFTAR PUSTAKA}

Boy, Sabarguna. (2004). Sistem Informasi Manajemen Rumah Sakit. Konsorsium Rumah Sakit Islam JATENG-DIY. Yogyakarta.

Boy, Sabarguna. (2009). Keselamatan dan Keamanan pada Rekam Medis Terkomputerisasi. UIPress. Jakarta.

Departemen Kesehatan Republik Indonesia. (1997). Pedoman Pengelolaan Rekam Medis Rumah Sakit di Indonesia. Direktorat Jenderal Pelayanan Medik. Jakarta.

Departemen Kesehatan Republik Indonesia. (2006). Pedoman Penyelenggaraan dan Prosedur Rekam Medis Rumah Sakit di Indonesia. Direktorat Jenderal Pelayanan Medik. Jakarta.

Dewan Pimpinan Pusat PORMIKI. (2009). Standar Kompetensi Administrator Informasi Kesehatan (Perekam Medis). Jakarta.

Gemala, R. H. et al. (2013). Pedoman Manajemen Informasi Kesehatan di Sarana Pelayanan Kesehatan Edisi Revisi 2. Penerbit Universitas Indonesia (UI-Press). Jakarta.

Rumah Sakit Al-Islam Bandung. (2016). Pedoman Penyelenggaraan Rekam Medis.

Peraturan Menteri Kesehatan Republik Indonesia Nomor 147 Tahun 2010 tentang Perizinan Rumah Sakit.

Peraturan Menteri Kesehatan Republik Indonesia Nomor 269 Tahun 2008 tentang Rekam Medis.

Peraturan Menteri Kesehatan Republik Indonesia Nomor 340 Tahun 2010 tentang Klasifikasi Rumah Sakit.

Peraturan Menteri Kesehatan Republik Indonesia Nomor 55 Tahun 2013 tentang Penyelenggaraan Pekerjaan Perekam Medis.

Peraturan Pemerintah Nomor 32 Tahun 1996 tentang Tenaga Kesehatan.

Undang-undang Nomor 29 Tahun 2004 tentang Praktik Kedokteran.

Undang-undang Nomor 44 Tahun 2009 tentang Rumah Sakit. 